\title{
Focus on marine resources may lead to reforms
}

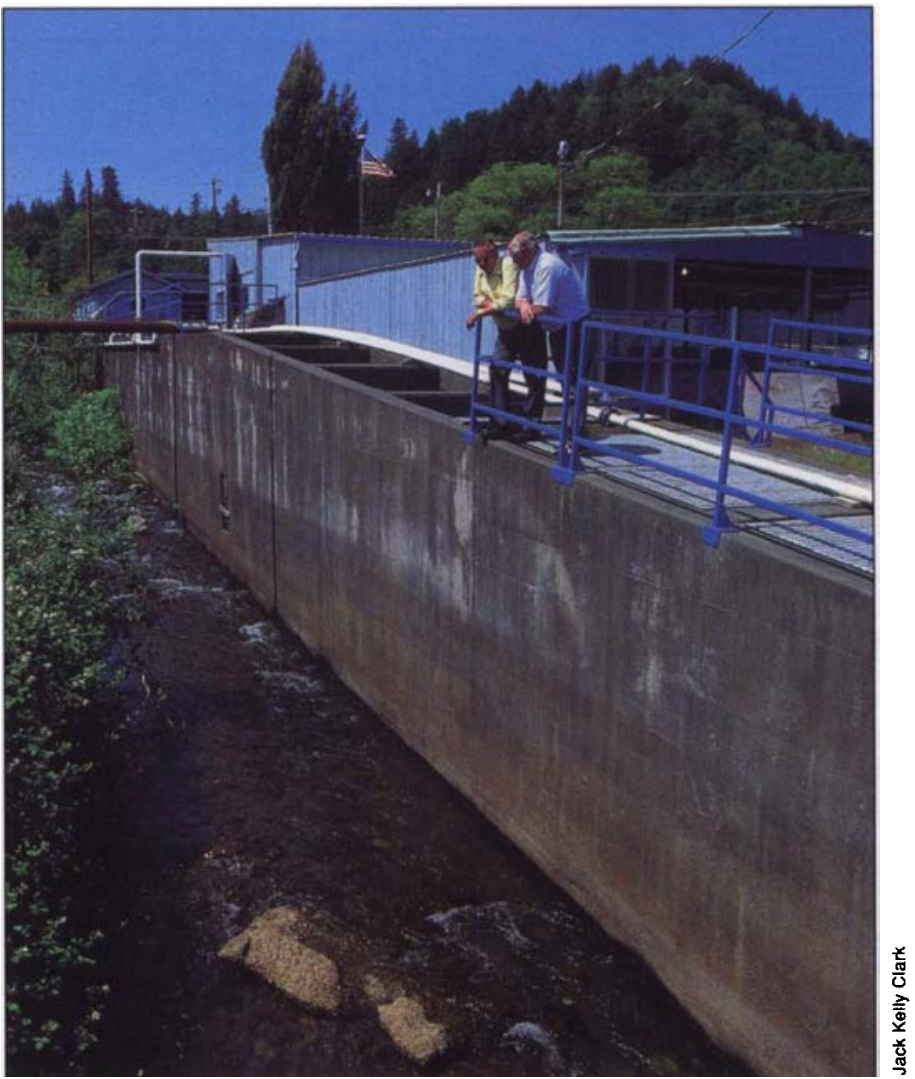

$\mathrm{T}$ he management of California's coastal and marine resources once again became a hot political issue in 1997. A state-sponsored conference, a hefty government report, and more than 50 ocean-related bills introduced in the state Legislature focused attention on the status of commercial fisheries, pollution of coastal waters and management of coastal and marine ecosystems, among other issues.

If passed and signed by Gov. Pete Wilson, the proposed laws would create substantial new protections for the natural resources along California's 1,100-mile coast. A report on ocean resources by the California Resources Agency, released in March at a conference in San Diego, addressed many of the same issues as the legislative initiatives, including the need for new approaches to sustainably manage ocean and coastal resources.

These developments come at a time of increased concern over the condition of marine resources worldwide. Roughly $70 \%$ of the world's commercially important marine fish populations are considered fully fished, overexploited, depleted, or slowly recovering, according to the United Nations Food and Agriculture Organiza-

Facing page, Big Creek Ecological Reserve, located 20 miles south of Big Sur. Photo by Alisa Fineman, Courtesy of UC Natural Reserve System.

Above, Scientists cross wild brood stock to enhance chinook and steelhead runs on the Smith River. Rowdy Creek Fish Hatchery, the only private, nonprofit salmon and steelhead hatchery in the state, uses new wild fish each year for breeding. tion. In the United States, $80 \%$ of the marine fish populations that have been assessed are classified by the National Marine Fisheries Service (NMFS) as fully fished or overexploited.

California's fisheries are a mix of healthy, depleted and recovering stocks. Some fishery stocks have rebounded after being seriously depleted, resulting in improved harvests in recent years. In some cases, catch restrictions played an important role in the recovery, while in others natural cycles were at least as important as human management policies. Healthy and recovering fish stocks include Northern anchovy, Pacific herring, California sardine and California halibut. Populations of other stocks, however, such as abalone and certain salmon runs, are drastically reduced.

"It's a mixed bag, depending on the speciessome stocks are very healthy, while others warrant concern," says Zeke Grader, executive director of the Pacific Coast Federation of Fishermen's Associations.

The management of marine resources involves both federal and state agencies. The NMFS, part of the U.S. Department of Commerce, has primary responsibility for marine fisheries in waters between 3 and 200 miles from the U.S. coast, while the state's authority extends out to 3 miles from the coast. The Pacific Fishery Management Council (PFMC), one of eight regional councils that advise the NMFS, develops management plans for marine fisheries from California to Washington. Three important fisheries - salmon, groundfish and anchovy - are

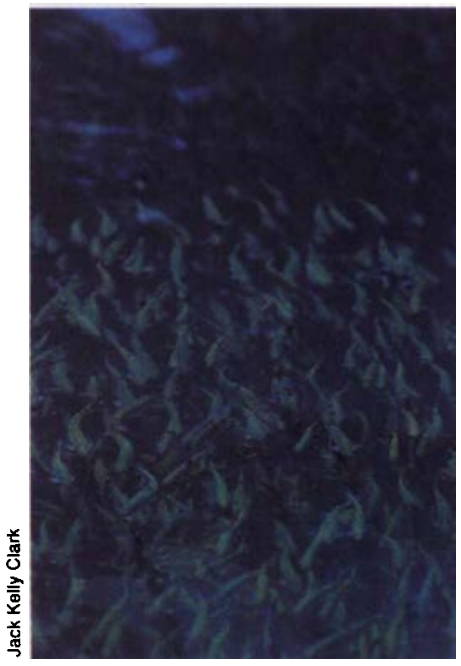

In the United States, $80 \%$ of the marine fish populations that have been assessed are... fully fished or overexploited. 
Fishing pressure has intensifled greatly on rockfish, far right, found off the California coast. Scientists are going undersea with a variety of advanced tools to learn more about rockfish habitats. This information enables resource managers to recommend prime areas or harvest refugia to replenish depleted stocks.

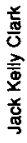

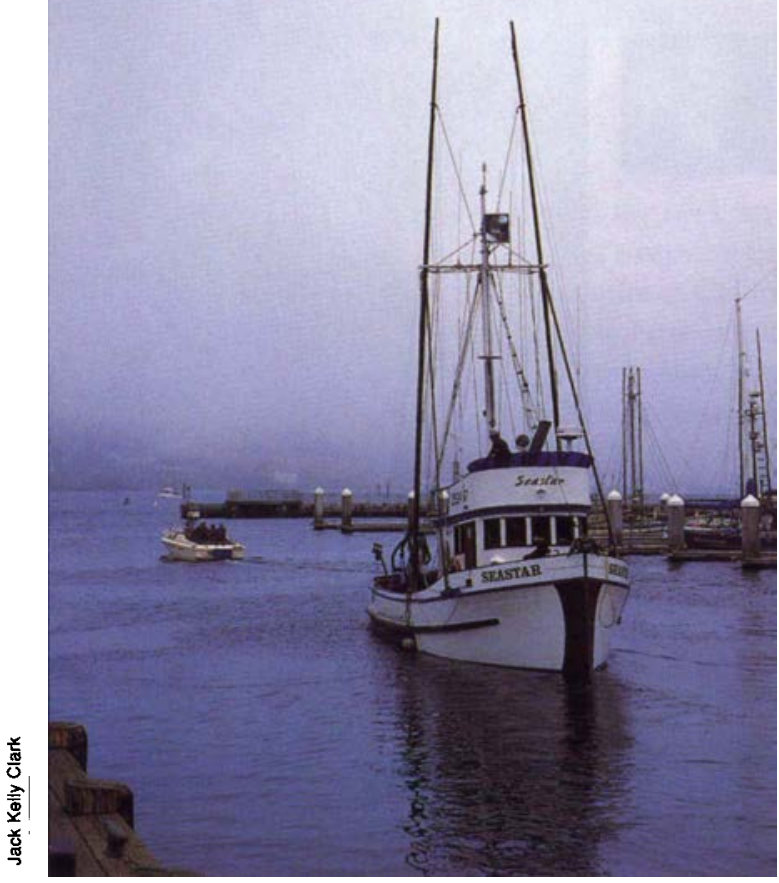

regulated by the NMFS under PFMC management plans. (PFMC management plans for groundfish, which include rockfish, flatfish, sablefish and whiting, cover the major species and groups, roughly 83 different species.) All other fisheries not specifically addressed by federal management plans are regulated by the states. For those species regulated by the NMFS, state rules applied within the 3-mile limit must be compatible with federal regulations, says Larry Six, executive director of the PFMC.

Several of the bills introduced in the California Legislature this year would establish or increase state protections of certain intensively harvested species, including squid and some rockfish. There are also bills aimed at restoring salmon and steelhead populations and raising the penalties for illegally taking abalone. One of the most far-reaching bills would completely overhaul the state's approach to managing marine life. Introduced by Assemblymember Fred Keeley of Santa Cruz, Assembly bill 1241 would create a

Several of the major bills introduced in the state Legislature this year are now "2-year" bills, meaning that they will not be voted on until 1998. This allows more time for lawmakers to work out the details of the proposed legislation. The 2-year bills include A.B. 1241 (Marine Life Management Commission) and A.B. 1315 (funding for DFG). The University of California has taken no official position on any of the proposed legislation. $-E d$ entire coastal ecosystem. The bill would shift regulatory control over ocean fishing from the Fish and Game Commission (FGC) to a new Marine Life Management Commission, whose members would have expertise in fisheries management. The new commission would have broader authority than the FGC has now to manage commercial fisheries. new commission to oversee the

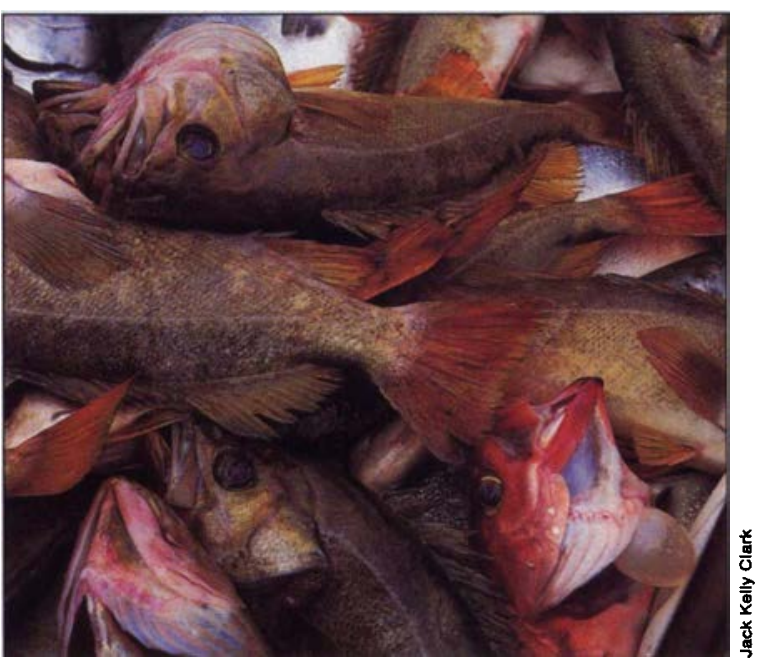

"Other states have policies that give fisheries experts the authority to put together enforceable management plans, and those efforts can be a useful guide for California," says Keeley.

California's Fish and Game Commission regulates sport fishing and hunting, but actually has very limited jurisdiction over commercial fisheries, says Robert Treanor, executive director of the Commission. The state Legislature has only delegated authority to the FGC for a few selected commercial fisheries, such as lobster, sea urchin, herring and to some extent, abalone. The Department of Fish and Game (DFG) enforces regulations, monitors commercial landings, performs research and makes recommendations to the FGC. The Legislature has retained authority over most commercial fisheries, setting management policies by enacting new laws.

"The commission is very supportive of looking at some form of reorganization of the existing process, because it appears not to be working where there are joint jurisdictions," Treanor says. "It would be best for a single entity to have full accountability."

\section{Abalone decline}

The decline of California's abalone populations is a classic example of how the current system fails to protect sea life, says Keeley. Abalone populations are on the verge of total collapse in Central and Southern California, primarily due to overharvesting, according to the DFG. In May, the FGC declared a temporary moratorium on all harvesting of red abalone south of San Francisco, closing the last commercial abalone fishery in California. Declines in white, pink, green and black abalone populations had already prompted the statewide closure of those fisheries. White abalone, once harvested by the continued on p. 8 


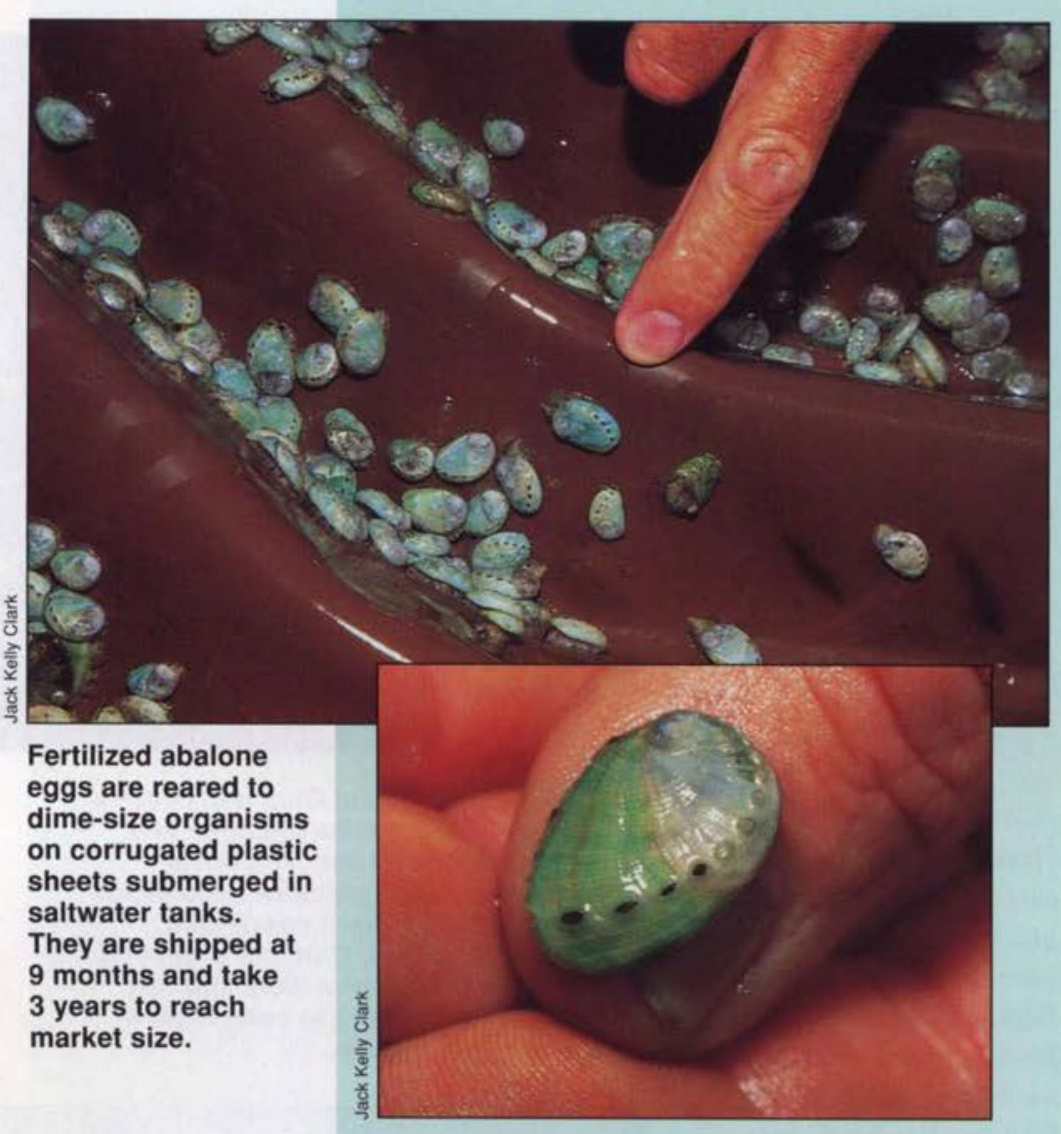

prevent the fresh water from entering them during these periods.

Meanwhile, the California Department of Fish and Game (CDFG) is struggling to protect the state's wild abalone populations. White abalone appear to be on the verge of extinction. Black abalone are suffering from a rickettsia-induced disease, called "withering syndrome," which has also been observed recently in other abalone species. Poaching is a major problem along the North Coast, where commercial harvesting and SCUBA-equipped sports diving have been banned for several decades.

For centuries, abalone have provided people with food and decorative shells used for adornment and trade. Today, the future of both cultured and wild stocks of abalone and other shellfish depends on sound management, clean water and habitat protection. To sustain abalone populations, it is important to implement sound management, reduce erosion and control nonpoint-source pollution from agricultural, residential and urban areas in order to protect coastal habitat and water quality.

P.G. Olin is Marine Advisor, UC Sea Grant Program, Sonoma County Cooperative Extension.

\section{continued from p. 6}

ton, appears doomed to extinction-one recent survey found 11 individuals, only one of which was female.

Mia Tegner, a research marine biologist at the Scripps Institution of Oceanography at UC San Diego, says there were many factors behind the state's failure to halt the demise of the abalone fishery. DFG biologists first recognized that abalone were in trouble in the 1970s. At that time, however, experts thought they could reverse the decline by seeding abalone beds with hatchery-reared juveniles. Unfortunately, says Tegner, optimism about the potential for seeding, which did not prove successful, was used to forestall actions to protect the fishery. Although some areas were closed and other actions taken to limit harvesting, abalone populations continued to decline. Poaching and inadequate funding for the DFG exacerbated the problem, Tegner says.

Predation by sea otters, whose population has expanded in recent decades, has reduced the abundance of abalone in certain areas; where sea otters are abundant, abalone are much less common and rarely attain harvestable size. But according to DFG biologists, sea otters are not a factor in the commercially harvested areas where abalone are most in need of protection. In Northern California, where commercial harvesting of abalone has been prohibited by state law since 1945, recreational harvesting by divers without SCUBA gear is still allowed and red abalone persist in sufficient numbers to support a very active sport fishery.

According to Treanor, the joint jurisdiction of the FGC and the Legislature has complicated management of abalone. For example, the Legislature had established in law the open and closed seasons for abalone, thereby constraining the FGC's ability to control the harvest more stringently by shortening the length of the open season. The FGC has authority to close a fishery for up to 2 years in a given area, but first it must have biological data demonstrating a problem, for which it usually relies on the DFG. The commission also holds public hearings before taking action so that interested parties can provide their input.

"The awkwardness of how fisheries are managed by the state can complicate mattersit's a very democratic process, and it takes a long time to reach a decision," says Cooperative Extension marine fisheries specialist Chris Dewees. 
During the 120-day moratorium on abalone harvesting, the FGC will consider various management alternatives, says Treanor. The commission has directed the DFG to develop an environmental document on abalone that includes a management plan, which is expected to be completed by December 1997.

\section{Coordination and funding}

In addition to the DFG, numerous state agencies have mandates and responsibilities in the marine environment, ranging from the California Coastal Commission to the Department of Health Services. One of the major recommendations contained in the Resources Agency report calls for the creation of a cabinet-level panel to coordinate the efforts of various state agencies and facilitate ecosystem wide planning for management of California's ocean and coastal waters.

Although improved planning and coordination may be important, the most pressing need is for increased funding, according to Assemblymember Keeley. Funding for agencies involved in preservation and restoration of coastal and marine ecosystems has dried up over the past decade, Keeley says. Several bills have been introduced that would provide increased funding for coastal protection.

"There is a tremendous backlog of needs for projects that have been planned but can't be implemented, including a $\$ 650$ million backlog in Coastal Conservancy and Wildlife Conservation Board projects for the coast," says Keeley.

A coastal bond act introduced by Keeley (A.B. 1000) would put a bond measure on the November 1998 ballot to provide $\$ 647$ million for acquiring and restoring wetlands, estuaries and other critical habitats for fish and wildlife. Another bill (A.B. 1315) would boost funding for the DFG by almost $\$ 30$ million.

Tegner maintains that inadequate funding has seriously limited the effectiveness of the DFG in protecting marine resources. "They are underfunded not only in terms of research but also for enforcement," Tegner says.

Although the overall budget for the department has generally increased over the years, it has not kept up with increasing costs and new mandates imposed by the Legislature, says DFG budget officer John Eastman.

"Certain programs may be spending the same amount of money as they did 10 years ago, but the effect of increased personnel costs and operating expenses means they aren't able to do as much with that money," Eastman says.

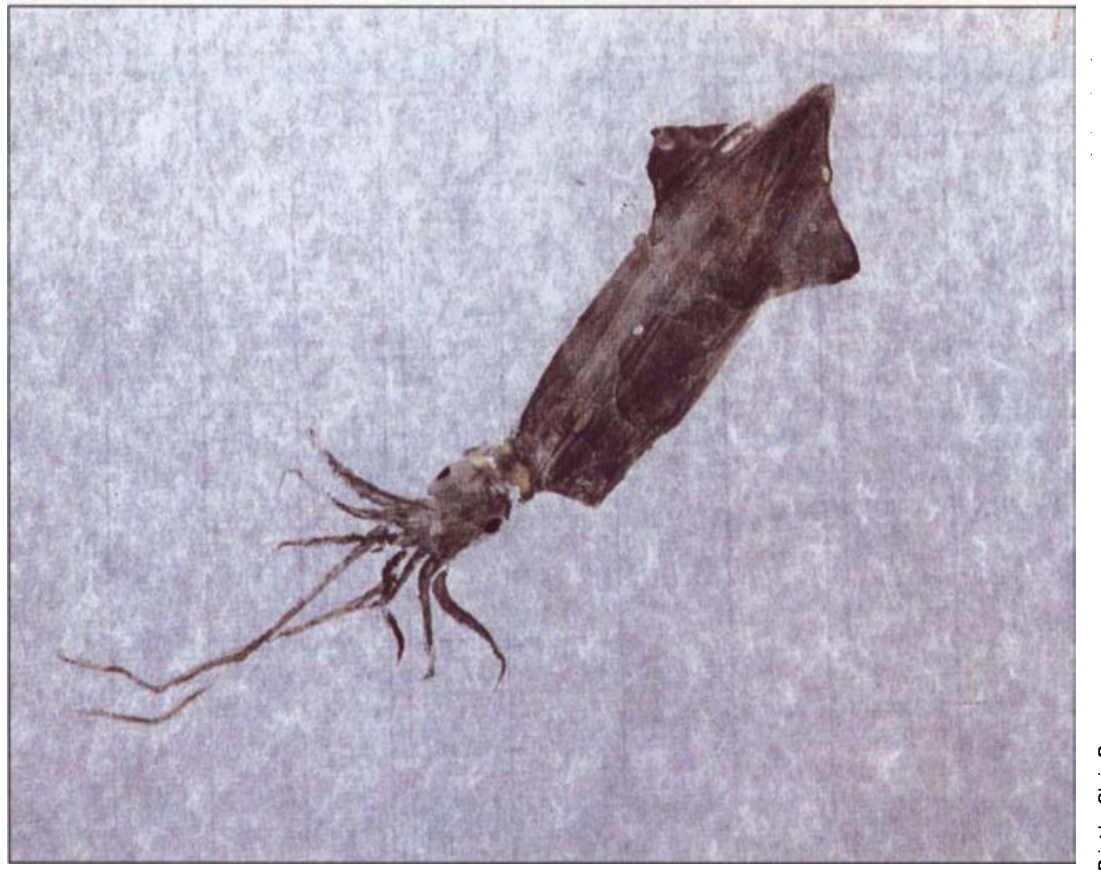

Landings of squid have increased dra-

A DFG request to increase funding for enforcement by more than $\$ 3$ million appears to be headed for approval, Eastman says. The added funds would, among other things, enable the DFG to purchase new vehicles and marine patrol boats.

\section{Research needs}

Research on the population biology of major fishery stocks is essential to guide management decisions. A lack of such research is the major concern in the California market squid fishery. Harvests of these 12-inch pelagic mollusks have increased dramatically in recent years, partly due to increased demand in the United States and overseas. Commercial landings in 1995 set a record for the state at 155 million pounds, valued at $\$ 22$ million. Little is known, however, about the current size, structure or status of the market squid population. Legislation

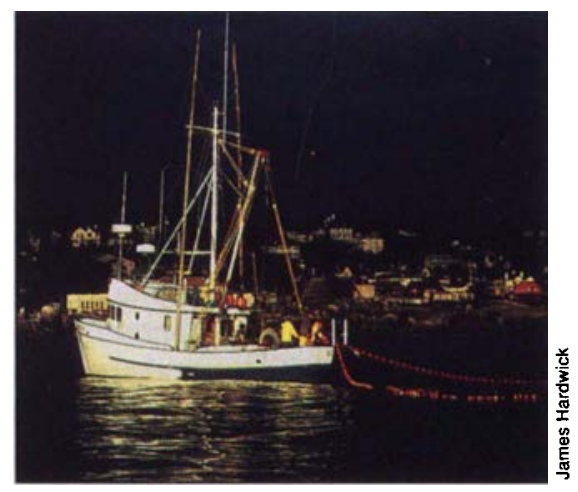
matically in the 1990 s in response to increased consumer demand worldwide.

This explosive growth in fishing pressure, combined with the lack of knowledge about squid populations, is a challenge for California fisheries managers. has been introduced to limit entry of new boats into the squid fleet until studies can be done to determine sustainable harvest rates.

"Squid is the big unknown," says Grader. "We need more research so we have some idea what the resource looks like in order to regulate the catch."

Market squid are prey for many fish, birds and marine mammals and play an important role in the coastal food web. The squid population tends to go through natural cycles, resulting in wide fluctuations in annual commercial 
landings, says Dewees. It is a very short-lived animal, with a lifespan of less than 2 years, so environmental and other factors that influence spawning success can have powerful effects on the size of the population. For example, the 1982$1983 \mathrm{El} \mathrm{Niño,} \mathrm{a} \mathrm{period} \mathrm{of} \mathrm{elevated} \mathrm{water} \mathrm{tempera-}$ tures and reduced coastal productivity, was followed by a steep drop in squid landings.

"There is probably a complex web of factors that determine their abundance, including food availability, spawning success, predators and fishing pressure," Dewees says.

The same can be said of other fisheries. A vaThe listing of coho salmon by the federal government as threatened throughout its California range has effectively closed a once thriving fishery. riety of factors can contribute to declines and fluctuations in marine fish populations. These include loss of habitat, water pollution and overfishing, as well as natural events such as drought, flooding, ocean temperature and current phenomena (see page 36 ).

"It is sometimes difficult to separate out the environmental effects from the human effects," Dewees says.

In the case of diminishing salmon and steelhead runs on the West Coast, the primary culprit is habitat loss. Salmon and steelhead trout are anadromous, returning to freshwater rivers and streams to spawn after spending most of their adult lives in the ocean. Dam construction, water diversions and stream degradation due to logging operations and other human activities have drastically reduced the amount of spawning habitat available to California's anadromous fish. Many efforts are now under way to protect and restore salmon spawning habitat in California (see p. 28).

In several cases, population declines have led to the listing of salmon species or races as threatened or endangered under state and federal statutes. For example, the listing of coho salmon by the federal government as threatened throughout its California range has effectively closed a once thriving fishery.

California has four distinct races, or runs, of chinook salmon, named for the time of year they enter fresh water to spawn: fall, late fall, winter and spring. Fall-run chinook are now the most numerous salmon in California. The winter-run chinook salmon in the Sacramento River, in contrast, is listed as endangered by both state and federal governments. Unfortunately, there is no way to quickly differentiate different runs of chinook salmon when they are caught in the ocean. Therefore, the PFMC must regulate the total harvest to protect the most vulnerable stocks, says executive director Six.

In 1995, commercial fishers in California landed more than 6 million pounds of chinook salmon worth $\$ 12$ million, up from 3 million pounds in 1994. This year, however, concern about three stocks found off the California coast - the Sacramento River winter run, Snake River fall run (a threatened species) and Klamath River fall run - prompted the PFMC to drastically limit the catch, despite an abundance of Sacramento River fall-run chinooks. In April, the council voted to close the entire California coast to commercial salmon fishing for 3 weeks in June, during the height of the season.

"Every year we predict the abundance of the major stocks to determine if closures are necessary; but we are likely to see a similar situation each year, because some of these stocks are very low and it will be a long time before they can be rebuilt," Six says.

Consumers aren't likely to notice much difference in the supply of fresh salmon, because of the availability of wild salmon from Alaska and Canada and farmed salmon raised in floating pens in Washington, Chile, Norway and elsewhere. The unprecedented restrictions will, however, seriously hurt California's commercial salmon fleet, already in decline due to increasingly strict regulations.

While the PFMC regulates the commercial salmon harvest, the state is responsible for protecting salmon in inland waters. The effects of water diversions from the Sacramento-San Joaquin Delta on salmon and other fish have caused a long-running conflict between water users and fishing and environmental groups. Serious negotiations are going on now, involving state and federal agencies, to design water regimes that will benefit the fish and still allow adequate water for agricultural and urban use (see Nov.-Dec. 1995 California Agriculture).

"It's a complicated issue," says Dewees. "They're negotiating how they might alter the levee systems to improve fish habitat, how to improve the transport of water so that it has less effect on the fish, and when to run the pumps [that divert water from the Delta]."

The Delta water diversions have been such a difficult and controversial issue that if a solution acceptable to all parties can be worked out through negotiations, this approach may serve as a model for the resolution of other conflicts over natural resources. 